\title{
MMP-2 and MMP-9 Serum Levels Change but their Gene Promoter Polymorphisms are not Associated with Late Phase I/R Injury or Rejection after Orthotopic Liver Transplantation
}

\author{
W. Rogier ten Hove ${ }^{1}$, Bert-Jan F. de Rooij ${ }^{1}$, Bart van Hoek ${ }^{1}$, Johan Ph. Kuyvenhoven ${ }^{1}$, \\ Martin J.W. Meijer ${ }^{1}$, Marlies van den Berg ${ }^{1}$, Johan J. van der Reijden ${ }^{1}$, Willem Verduyn ${ }^{2}$, \\ Jeroen Dubbeld ${ }^{3}$, Daniel W. Hommes ${ }^{1}$, Cornelis B.H.W. Lamers ${ }^{1}$ and Hein W. Verspaget ${ }^{1, *}$
}

\author{
${ }^{I}$ Department of Gastroenterology and Hepatology; ${ }^{2}$ Department of Immunohematology and Blood Transfusion / Euro- \\ transplant Reference Laboratory and ${ }^{3}$ Department of Surgery, Leiden University Medical Center, Leiden, The Nether- \\ lands
}

\begin{abstract}
Introduction. Matrix metalloproteinases (MMPs) are involved in connective tissue remodeling processes associated with chronic liver disease and complications after orthotopic liver transplantation (OLT). Genetic variations in the promoter region of the MMP-2 and MMP-9 genes are thought to contribute not only to their transcription rate but may also have predisposing clinical impact.

Methods. MMP-2 and MMP-9 gene promoter polymorphisms were analyzed in 109 patients who underwent an OLT. The relationship between these MMP polymorphisms in the donor and recipient DNA with the development of ischemia/reperfusion (I/R) injury and rejection after OLT was evaluated. In addition, serum MMP-2 and MMP-9 levels were determined to illustrate potential phenotypical consequences in these patients.

Results. The MMP-2 and -9 genotypes of the donor and recipient or a donor/recipient mismatch and chimerism were not associated with the development of late phase I/R injury or rejection in the OLT patients, although serological differences in the MMP levels did occur. The MMP-2 and -9 genotype distribution did also not have a major impact on the respective serum levels in patients that underwent an OLT.

Conclusions. MMP-2 and MMP-9 gene polymorphisms do not seem to contribute to late phase I/R injury or rejection after liver transplantation. Serological changes in the MMP-2 and MMP-9 levels appear to occur independent of the MMP genotype after transplantation of the liver.
\end{abstract}

\section{INTRODUCTION}

Matrix metalloproteinases (MMPs) comprise a large family of proteolytic enzymes that are important in physiological and disease-related extracellular matrix remodeling. The gelatinases MMP-2 and MMP-9 are capable of digesting components of the connective tissue matrix and type IV collagen within basement membranes. These MMPs are considered to play an important role in cancer development, vascular remodeling, fibrosis and inflammation $[1,2]$. In recent years it has become evident that also in the liver MMPs are involved in diverse (patho)physiological processes, like fibrosis, hepatocellular carcinoma development and liver transplantation [3].

MMP activity is transcriptionally regulated by various factors and controlled by tightly regulated activation of latent pro-enzymes and by interaction with endogenous inhibitors such as tissue inhibitors of metalloproteinases (TIMPs). Recently, several single nucleotide polymorphisms (SNP) in the gene promoter regions of MMPs have been found with a

*Address correspondence to this author at the Department of Gastroenterology and Hepatology, Leiden University Medical Center, C4-P, PO. Box 9600, 2300 RC Leiden, The Netherlands; Tel: +31-71-5262680; Fax: +3171-5248115; E-mail: H.W.Verspaget@lumc.nl functional impact on the transcription rate. The $\mathrm{C} / \mathrm{T}$ transition at position -1306 in the promoter of MMP-2, which abolishes the Sp 1 binding site, and the G/A transition at position -1575 , which is located next to an estrogen receptor binding site, leads to decreased mRNA transcription $[4,5]$. In several studies an association was demonstrated between MMP-2 polymorphisms and the development of cancer [6, 7]. In the MMP-9 gene a SNP at position -1562 is due to a $\mathrm{C}$ to $\mathrm{T}$ substitution in the promoter region [8]. In vitro studies have shown that this transition results in loss of binding of a nuclear repression protein in this region and an increase in transcriptional activity in macrophages. This functional effect on transcription was associated with the severity of coronary atherosclerosis [8]. In accordance with the increased activity of the $-1562 \mathrm{~T}$ allele this allele was found to be associated with elevated MMP-9 plasma levels in patients with cardiovascular disease [9].

In the liver, the hepatic stellate cell is suggested to be the main cellular source of MMP-2. Liver fibrosis is a dynamic process in which activated stellate cells are involved in the synthesis of matrix proteins and in the regulation of matrix degradation. Increased mRNA expression of MMP-2 was reported in liver biopsy samples of patients with cirrhosis [10]. In addition, serum levels of MMP-2 are found to be 
increased in patients with chronic liver disease and to correlate with the severity of the liver function impairment [11]. MMP-9 is released predominantly from neutrophils and macrophages, but the principal source in the liver is thought to be the Kupffer cell, the resident macrophage of the liver [12]. MMP-2 and MMP-9 are presumed to play a critical role in cold storage injury during preservation and in the subsequent reperfusion injury of liver grafts [13]. The extracellular matrix may also be an important target in the process of acute rejection after orthotopic liver transplantation (OLT). In a previous study we demonstrated elevated serum levels of MMP-9 at 1 week after OLT in patients with acute allograft rejection [14].

The aim of the present study was to establish the relationship between MMP-2 and MMP-9 gene promoter polymorphisms in the donor and recipient DNA and the respective MMP serum levels with the development of late phase ischemia/reperfusion (I/R) injury of rejection after OLT.

\section{PATIENTS AND METHODS}

\section{Study Design}

Our study group consisted of 109 patients who underwent an OLT. All blood and tissue samples from these patients were collected prospectively and retrospectively analysed. Longitudinal MMP serum levels were measured in a representative subset of 27 patients. MMP genotype distribution in this subset was similar to the study group of 109 patients. Serum samples for MMP measurement were collected at 7 time points: before transplantation (I) and at 2 days (II), 1 week (III), 1 month (IV), 3 months (V), 6 months (VI) and 1 year (VII) after OLT. Serum samples were stored at $-70{ }^{\circ} \mathrm{C}$ until use. MMP-2 and MMP-9 concentrations were determined using highly specific enzyme-linked immunosorbent assays, which measure the pro-enzyme, active- and inhibitor complexed forms, as described previously $[15,16]$.

\section{Ischemia and Reperfusion Injury}

The degree of late phase hepatocellular injury was evaluated by measurement of aspartate aminotransferase (AST) during the first week after OLT. Patients were classified into 2 groups depending on whether the serum AST peak was lower than 1,500 IU/L (no or mild I/R injury) or higher than 1,500 IU/L (more severe I/R injury), respectively $[17,18]$.

\section{Rejection}

Liver biopsies were taken according to our protocol at approximately 1 week after OLT or when there was a suspicion of rejection. Acute allograft rejection was graded according to the Banff scheme and the histopathological severity was evaluated by three specific features (portal inflammation, bile duct inflammation/damage, venous endothelial inflammation) [19]. In this study patients were divided into 2 groups according to the presence or absence of acute allograft rejection at approximately 1 week. The rejection had to be clinically relevant, i.e. histologically confirmed and treated with additional immunosuppression.

\section{Determination of SNPs of the MMPs}

Genomic DNA was extracted by routine methods from peripheral blood leukocytes. In addition, DNA samples from the blood of the liver donor were obtained from the Euro- transplant Reference Laboratory and DNA was isolated from liver biopsy tissue of the allograft in the recipients obtained several months (median 17, range 5 to 48) after OLT.

The $-1306 \mathrm{C} / \mathrm{T}$ MMP-2 gene promoter polymorphism was determined by tetra-primer amplification refractory mutation system- polymerase chain reaction (PCR) analysis, the principles of which are described elsewhere [20, 21], and confirmed by direct sequence analysis of 4 patients. Briefly, the region flanking the SNP was amplified with outer primers 5'-ACCAGACAAGCCTGAACTTGTCTGA-3' and 5'TGTGACAACCGTCTCTGAGGAATG-3' together with inner allelic specific primers 5'-ATATTCCCCACCCAGCACGCT-3' and 5'-GCTGAGACCTGAAGAGCTAAAGAGTTG-3'. Genotypes CC, CT and TT $(542+379 ; 542+379+$ $211 ; 542+211 \mathrm{bp}$, respectively) are easily identified from the migration pattern on agarose gels. The other gene promoter polymorphisms were determined as described previously $[20,22]$. In brief: transition polymorphism G/A at -1575 of the MMP-2 promoter gene was determined by PCR amplification using outer primers also used for the -1306 polymorphism followed by restriction enzyme fragment length (RFLP) analysis with BspH I to produce 542, 542+458+83 or $458+83$ bp fragments indicating the GG, GA and AA genotype, respectively. The SNP C/T at position -1562 of the MMP-9 gene promoter was determined by PCR-RFLP. The SNP flanking region was amplified using primers 5' ATGGCTCATGCCCGTAATC-3' and 5'-TCACCTTCTTCAAAGCCCTATT-3' followed by restriction analysis with Sph I to produce $352,352+207+145$ or $207+145$ bp fragments in case of CC, CT and TT genotype, respectively.

\section{Statistical Analysis}

Genotype frequencies were analyzed by generating twoby-two contingency tables and statistical analysis was performed using the Chi-square test or Fischer's Exact test, when appropriate, using SPSS software (SPSS Inc; Chicago, IL, USA). Differences in MMP levels according to the genotype and disease complications were assessed by the MannWhitney $U$ or the Wilcoxon signed ranks test for nonparametric data [14, 23]. MMP levels are expressed as mean \pm S.E.M. Differences were considered to be significant at Pvalues of $\leq 0.05$.

\section{RESULTS}

\section{Patients}

Our study group consisted of 109 patients (70 male) who underwent an OLT. The median age was 47 years (range 16 to 67$) .30$ patients had chronic viral hepatitis, 26 patients had cholestatic liver disease, 21 patients had alcohol-related liver disease, and a miscellaneous group $(n=32)$ was included, consisting of 7 patients with autoimmune hepatitis, 9 with cryptogenic liver cirrhosis, 4 with neoplastic disorders, 2 with azathioprine induced liver cirrhosis, 2 with polycystic liver disease, 1 with acute fatty liver of pregnancy, 4 with Budd Chiari Syndrome, two patients with Wilson's disease and one patient with alpha-1 antitrypsin deficiency.

\section{The Role of MMP Polymorphisms in Liver Transplanta-} tion

The frequencies of the donor and recipient MMP-2 and MMP-9 genotypes in relation to the development of IR- 
injury and rejection after OLT are shown in Table $\mathbf{1}$. Because the gene polymorphisms at the -1306 and the -1575 position of the MMP-2 promoter were found to be in complete linkage disequilibrium only the data at the -1306 position are given. Late phase I/R injury was graded "more severe" in 33 of 109 patients after OLT, and rejection had occurred in 20 patients. The genotype frequencies for MMP-9 determined in the donor and recipient DNA of patients with or without late phase I/R injury, and with or without rejection, however, were not significantly different (Table 1A). Also, the MMP-2 genotype frequency of the donor and recipient were not significantly different according to the development of $\mathrm{I} / \mathrm{R}$ injury or rejection, although the donors were found the have a significantly different genotype frequency distribution from the recipients (Table 1B). There- fore, we assessed the clinical impact of such a mismatch in allelic composition at the MMP-2 and MMP-9 SNP loci between the donor and recipient. However, no statistically significant differences between the presence or absence of a mismatch at $-1306 \mathrm{C} / \mathrm{T}$ MMP-2 or $-1562 \mathrm{C} / \mathrm{T}$ MMP-9 were found in relation to the development of $\mathrm{I} / \mathrm{R}$ injury and to rejection after liver transplantation (Table 2). Obviously, due to the donor-recipient differences, the frequency of a mismatch in MMP-2 was significantly higher than in MMP-9 (57.8\% versus $33.9 \%$, Table 2). Serum levels of MMP-2 are increased in patients with chronic liver disease and therefore a drop of MMP-2 levels was expected after OLT [11]. This decrease indeed was seen, as shown in Fig. (1), but occurred independent of the genotype. Serum levels of MMP-9 peak at 1 week after OLT, which is associated with acute allograft

Table 1. The Development of IR-Injury and Rejection after OLT Stratified According to Gene Promoter Polymorphisms at MMP9 (A) and MMP-2 (B) SNP loci in Donor and Recipient

\begin{tabular}{|c|c|c|c|c|c|}
\hline \multirow{3}{*}{$\begin{array}{l}\text { A } \\
\text { Complication }\end{array}$} & \multirow{3}{*}{ Genotype } & \multicolumn{4}{|c|}{-1562 C/T MMP-9 } \\
\hline & & \multicolumn{2}{|c|}{ Donor } & \multicolumn{2}{|c|}{ Recipient } \\
\hline & & $\begin{array}{c}\text { CC } \\
\mathrm{n}(\%)\end{array}$ & $\begin{array}{c}\text { CT } \\
\text { n }(\%)\end{array}$ & $\begin{array}{c}\text { CC } \\
\text { n }(\%)\end{array}$ & $\begin{array}{c}\text { CT } \\
\text { n }(\%)\end{array}$ \\
\hline Statistical significance & & \multicolumn{2}{|c|}{$X^{2}=1.7 ; \mathrm{P}=0.19$} & \multicolumn{2}{|c|}{$X^{2}=0.3 ; \mathrm{P}=0.58$} \\
\hline Rejection & $\begin{array}{l}\text { No } \\
\text { Yes }\end{array}$ & $\begin{array}{l}66(74.2) \\
14(70.0)\end{array}$ & $\begin{array}{c}23(25.8) \\
6(30.0)\end{array}$ & $\begin{array}{l}67(75.3) \\
16(80.0)\end{array}$ & $\begin{array}{c}22(24.7) \\
4(20.0)\end{array}$ \\
\hline Statistical significance & & \multicolumn{4}{|c|}{$X^{2}=0.1 ; \mathrm{P}=0.75$} \\
\hline
\end{tabular}

\begin{tabular}{|c|c|c|c|c|c|}
\hline \multirow{3}{*}{$\begin{array}{l}\text { B } \\
\text { Complication }\end{array}$} & \multirow{3}{*}{ Genotype } & \multicolumn{4}{|c|}{-1306 C/T MMP-2 } \\
\hline & & \multicolumn{2}{|c|}{ Donor } & \multicolumn{2}{|c|}{ Recipient } \\
\hline & & $\begin{array}{c}\text { CC } \\
\mathbf{n}(\%)\end{array}$ & $\begin{array}{c}\text { CC \& CT } \\
\text { n }(\%)\end{array}$ & $\begin{array}{c}\text { CC } \\
\text { n }(\%)\end{array}$ & $\begin{array}{c}\text { CC \& CT } \\
\text { n }(\%)\end{array}$ \\
\hline Statistical significance & & \multicolumn{2}{|c|}{$X^{2}=0.8 ; \mathrm{P}=0.37$} & \multicolumn{2}{|c|}{$X^{2}=0.4 ; \mathrm{P}=0.53$} \\
\hline Rejection & $\begin{array}{l}\text { No } \\
\text { Yes }\end{array}$ & $\begin{array}{c}43(48.3) \\
7(35.0)\end{array}$ & $\begin{array}{l}46(51.7) \\
13(65.0)\end{array}$ & $\begin{array}{l}62(69.7) \\
12(60.0)\end{array}$ & $\begin{array}{c}27(30.3) \\
8(40.0)\end{array}$ \\
\hline Statistical significance & & \multicolumn{4}{|c|}{$X^{2}=9.9 ; \mathrm{P}=0.002$} \\
\hline
\end{tabular}


Table 2. The Development of IR-Injury and Rejection after OLT Stratified According to the Presence of a Mismatch in Allelic Composition at MMP-2 and MMP-9 SNP Loci between Donor and Recipient

\begin{tabular}{|c|c|c|c|c|c|}
\hline Complication & Genotype & \multicolumn{2}{|c|}{$\begin{array}{c}-1306 \text { C/T MMP-2 } \\
\text { Mismatch }\end{array}$} & \multicolumn{2}{|c|}{$\begin{array}{c}-1562 \text { C/T MMP-9 } \\
\text { Mismatch }\end{array}$} \\
\hline IR-injury & $\begin{array}{l}\text { No } \\
\text { Yes }\end{array}$ & $\begin{array}{l}33(43.4) \\
13(39.4)\end{array}$ & $\begin{array}{l}43(56.6) \\
20(60.6)\end{array}$ & $\begin{array}{l}48(63.2) \\
24(72.7)\end{array}$ & $\begin{array}{l}28(36.8) \\
9(27.3)\end{array}$ \\
\hline Rejection & $\begin{array}{l}\text { No } \\
\text { Yes }\end{array}$ & $\begin{array}{l}39(43.8) \\
7(35.0)\end{array}$ & $\begin{array}{l}50(56.2) \\
13(65.0)\end{array}$ & $\begin{array}{l}58(65.2) \\
14(70.0)\end{array}$ & $\begin{array}{l}31(34.8) \\
6(30.0)\end{array}$ \\
\hline Statistical significance & & \multicolumn{2}{|c|}{$X^{2}=0.5 ; \mathrm{P}=0.47$} & \multicolumn{2}{|c|}{$X^{2}=0.2 ; \mathrm{P}=0.68$} \\
\hline
\end{tabular}

rejection, as previously reported [14]. Irrespective of a genotype mismatch between the donor and the recipient, we found a comparable serum MMP-9 peak and pattern over time (Fig. 1). In some patients with a mismatch evidence of chimerism was demonstrated in the DNA samples from the liver biopsy tissue of the allograft. The chimerism was identified by the presence of an MMP SNP signal from the recipient in addition to the strong signal of the donor in the DNA from the allograft liver biopsy (Fig. 2). These chimerisms were demonstrated in $37.5 \%$ of patients with a MMP-9 mismatch and in $62.5 \%$ of patients with a MMP-2 mismatch, but were of no additional clinical significance.

\section{DISCUSSION}

Our study shows that the $-1306 \mathrm{C} / \mathrm{T}$ MMP-2 and the $1562 \mathrm{C} / \mathrm{T}$ MMP-9 gene promoter polymorphisms, determined in the donor and the recipient, are not associated with rejection or late phase I/R injury after OLT. Moreover, the consistent changes in the serum MMP-2 and MMP-9 levels after OLT evolve independent of the genotypes and donorrecipient mismatches.

Polymorphisms in the promoter region of a number of MMP genes have been shown to influence MMP gene expression and/or were found to be associated with susceptibility of disease like coronary atherosclerosis, aneurysms, and cancer [24]. For example, a functional SNP in the promoter of the MMP-2 gene $(-1306 \mathrm{C} / \mathrm{T})$ leads to a diminished promoter activity and is principally studied in cancer [5]. In case-control studies from China it was demonstrated that the -1306 CC MMP-2 genotype may constitute a common susceptibility factor for cancer of the breast, lung, and stomach, whereas in hepatocellular carcinoma it was not $[6,7,25,26]$. Liver fibrosis is a highly dynamic process in which multiple genes may interact with environmental factors. Polymorphisms in genes encoding immunoregulatory proteins, proinflammatory cytokines, and fibrinogenic factors may influence disease progression [27]. MMPs play an important role in remodeling of the hepatic extracellular matrix and increased expression of MMP-2 was found in human liver fibrosis [10, 28]. However, studies on MMP-2 promoter polymorphisms have never been reported in patients with chronic liver disease. In the present study the serum MMP-2 levels in patients with diverse chronic liver disease were increased pre-OLT and decreased significantly over time after OLT but unrelated to the $-1306 \mathrm{C} / \mathrm{T}$ MMP-2 genotype and donor-recipient mismatch. Apparently, MMP-2 expression changes in liver disease processes and may even be indicative for disease progression, as reported for hepatic fibrosis [29] and recurrence of hepatocellular carcinoma [30], but this may occur unrelated to the genotypic constitution. Other studies similarly demonstrated that disease related changes in the hepatic mRNA MMP-3 expression was determined by the MMP-3 (-1171 5A/6A) promoter polymorphism, while the genotype distribution was not significantly different between controls, patients with chronic hepatitis, and patients with cirrhosis [31, 32].

The expression of MMP-9 is regulated primarily at the transcription level in response to different regulators such as interleukin-1, tumor necrosis factor-alpha, and epidermal growth factor [2]. The functionally most important SNP at position -1562 in the MMP-9 gene leads to increased transcriptional activity in individuals with the $\mathrm{T}$ allele and is associated with severity of coronary atherosclerosis [8]. In another study, the $\mathrm{T}$ allele of the $-1562 \mathrm{C} / \mathrm{T}$ polymorphism was associated with elevated MMP-9 serum levels, but no association with cardiovascular mortality was found [9]. Studies on functional polymorphisms of MMP-9 in patients with pulmonary emphysema [33], abdominal aneurysm [34], end-stage renal disease [35], multiple sclerosis [36], and intracranial aneurysms revealed contradictory results $[37,38]$, In liver disease it has become obvious that MMP-9 may have a very important impact, as illustrated by the predictive value for recurrence of hepatocellular carcinoma after liver transplantation [30], the protection against hepatic I/R injury in MMP-9 deficient/neutralized mice [39, 40] and a contribu- 

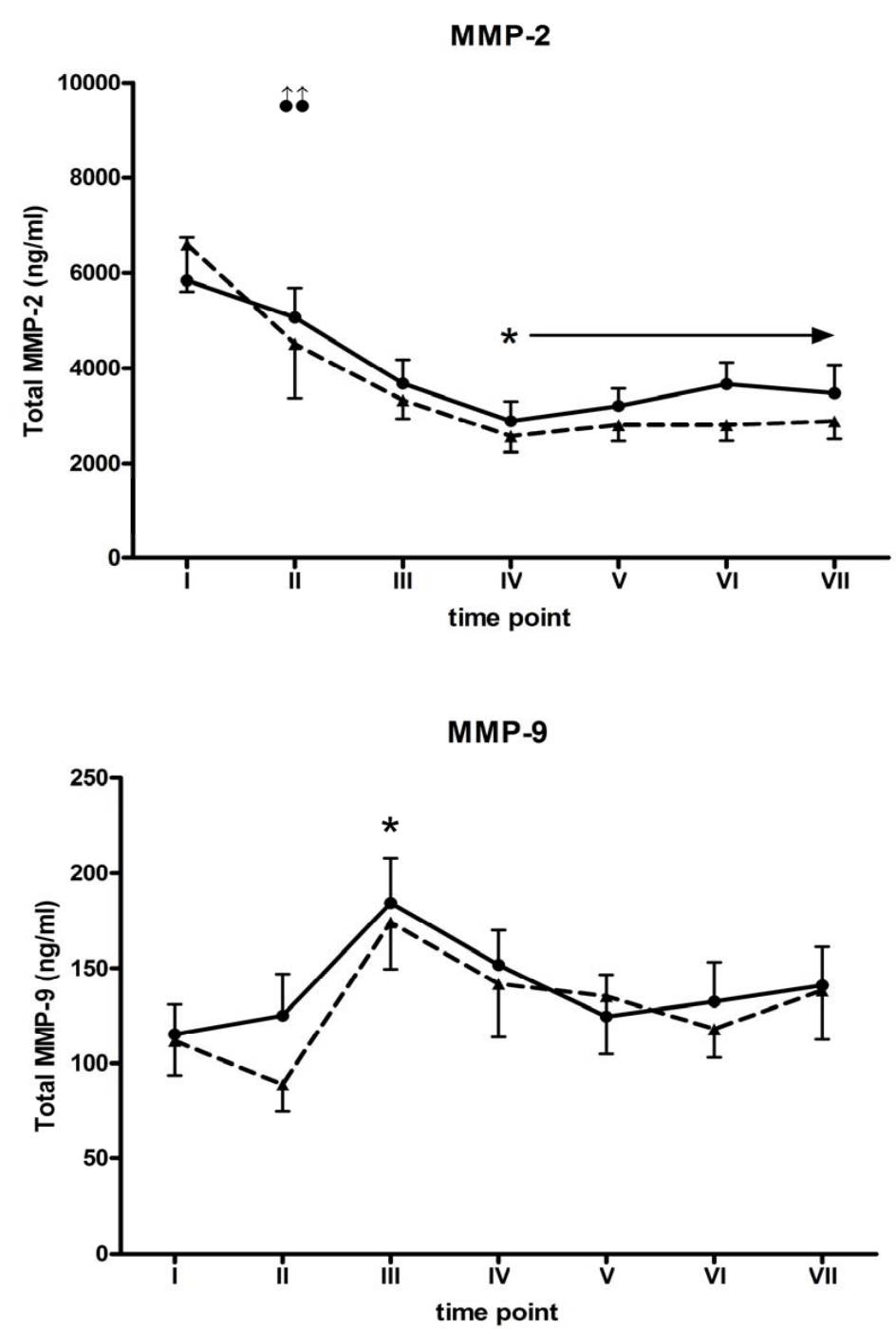

\footnotetext{
-: Patients without a mismatch between donor and recipient; $\boldsymbol{\Delta}$ : Patients with a mismatch.

* MMP-2: $\mathrm{P}<0.01$ for both groups compared to time point $\mathrm{I}, \bullet$ two outliers.

* MMP-9: $\mathrm{P}<0.02$ time point III compared to time point I, for both groups.
}

Fig. (1). MMP-2 en MMP-9 serum concentrations before transplantation (I) and at 2 days (II), 1 week (III), 1 month (IV), 3 months (V), 6 months (VI) and 1 year (VII) after OLT. Data are expressed as mean \pm SEM.

tion to the progression of chronic liver disease [41]. We found a peak in serum MMP-9 levels at 1 week after OLT in patients with rejection. The MMP-9 is most likely derived from infiltrating neutrophils in the portal triad of the liver or from Kuppfer cells activated by cytokines from the infiltrating cells [14]. However, the serological changes in MMP-9 were found to be unrelated to the $-1562 \mathrm{C} / \mathrm{T}$ MMP-9 gene promoter polymorphism of the patients, donors and the presence of mismatch.

In previous studies we demonstrated that MMP-9, but not MMP-2, could play an important role in immediate I/R injury [23] and in acute allograft rejection after liver transplantation [14]. In the present study we assessed the impact of the donor MMP genotypes on the outcome and complications after liver transplantation but no associations were found. We did observe significant differences in the MMP-2 genotype distribution between donors and recipients but not in relation to clinical complications as $\mathrm{I} / \mathrm{R}$ and rejection after OLT. Also the presence of a mismatch in the MMP genotype between the donor and the recipient and the evidence of chimerism in the liver biopsy tissue of the allograft were found not to contribute to the clinical complications after transplantation. The development of the chimerism we observed might in part be explained by the presence of lymphocytes and Kupffer cells of recipient origin, but recently it was demonstrated that recipient-derived cells can also replace biliary epithelium, endothelium, and even hepatocytes in liver transplants [42].

In conclusion, this study indicates that MMP-2 and MMP9 gene promoter polymorphisms are not associated with late phase I/R injury or rejection after liver transplantation. Furthermore, functionally and clinically relevant changes in the 

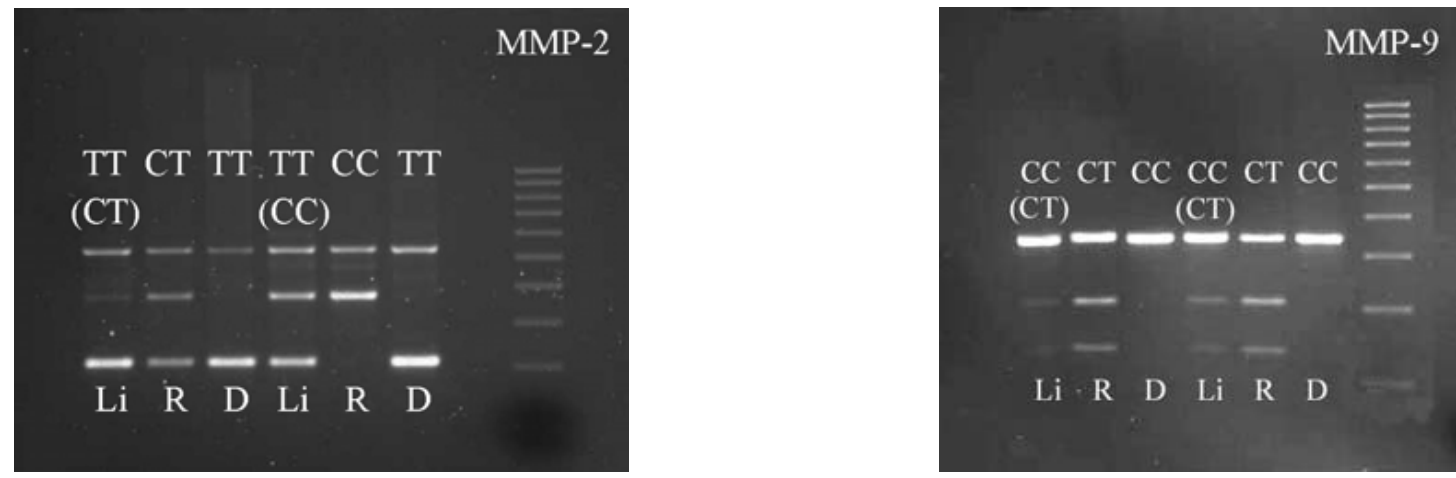

Fig. (2). MMP genotype chimerism, indicated by genotypes between brackets, in OLT allografts based on the SNP analysis of the MMP-2 $1306 \mathrm{C} / \mathrm{T}$ locus and the MMP-9 $-1562 \mathrm{C} / \mathrm{T}$ locus of sets of DNA from the transplanted liver (Li) and blood leukocytes of the recipient (R) and from blood leukocytes of the donor (D).

serum levels of MMP-2 and MMP-9 in patients who underwent OLT develop independent of the MMP promoter genotype. Although MMPs are involved in both the progression and resolution of disease processes in the liver [43], the exact contribution of the MMP genes still has to be elucidated.

\section{ACKNOWLEDGEMENTS}

W. van Duijn and E.S.M. de Jonge-Muller from the department of Gastroenterology and Hepatology, Leiden University Medical Center, Leiden, The Netherlands and Dr. R. Hanemaaijer and Dr. J.H. Verheijen from TNO Quality of Life, Biomedical Research, Leiden, The Netherlands, are gratefully acknowledged for their technical assistance.

\section{ABBREVIATIONS}

MMP: matrix metalloproteinases; TIMP: tissue inhibitors of metalloproteinases; SNP: single nucleotide polymorphism; OLT: orthotopic liver transplantation; I/R: ischemia/reperfusion; AST: aspartate aminotransferase; PCR: polymerase chain reaction; RFLP: restriction enzyme fragment length polymorphism.

\section{REFERENCES}

[1] Shapiro SD. Matrix metalloproteinase degradation of extracellular matrix: biological consequences. Curr Opin Cell Biol 1998; 10(5): $602-8$.

[2] Sternlicht MD, Werb Z. How matrix metalloproteinases regulate cell behavior. Annu Rev Cell Dev Biol 2001; 17: 463-516.

[3] Verspaget HW, Kuyvenhoven JP, Sier CF, van Hoek B. In: Lendeckel U, Hooper NM Eds. Matrix metalloproteinases in chronic liver disease and liver transplantation. Proteases in Biology and Disease 5: Proteases in Gastrointestinal Tissues. Dordrecht, the Netherlands: Springer 2006; 209-34.

[4] Harendza S, Lovett DH, Panzer U, Lukacs Z, Kuhnl P, Stahl RA. Linked common polymorphisms in the gelatinase a promoter are associated with diminished transcriptional response to estrogen and genetic fitness. J Biol Chem 2003; 278(23): 20490-9.

[5] Price SJ, Greaves DR, Watkins H. Identification of novel, functional genetic variants in the human matrix metalloproteinase-2 gene: role of $\mathrm{Sp} 1$ in allele-specific transcriptional regulation. J Biol Chem 2001; 276(10): 7549-58.

[6] Miao X, Yu C, Tan W, et al. A functional polymorphism in the matrix metalloproteinase-2 gene promoter $(-1306 \mathrm{C} / \mathrm{T})$ is associated with risk of development but not metastasis of gastric cardia adenocarcinoma. Cancer Res 2003; 63(14): 3987-90.

[7] Zhou Y, Yu C, Miao X, et al. Substantial reduction in risk of breast cancer associated with genetic polymorphisms in the promoters of the matrix metalloproteinase- 2 and tissue inhibitor of metalloproteinase-2 genes. Carcinogenesis 2004; 25(3): 399-404.
[8] Zhang B, Ye S, Herrmann SM, Eriksson P, et al. Functional polymorphism in the regulatory region of gelatinase $\mathrm{B}$ gene in relation to severity of coronary atherosclerosis. Circulation 1999; 99(14): 1788-94.

[9] Blankenberg S, Rupprecht HJ, Poirier O, et al. Plasma concentrations and genetic variation of matrix metalloproteinase 9 and prognosis of patients with cardiovascular disease. Circulation 2003; 107(12): 1579-85.

[10] Milani S, Herbst H, Schuppan D, et al. Differential expression of matrix-metalloproteinase- 1 and -2 genes in normal and fibrotic human liver. Am J Pathol 1994; 144(3): 528-37.

[11] Kuyvenhoven JP, van Hoek B, Blom E, et al. Assessment of the clinical significance of serum matrix metalloproteinases MMP-2 and MMP-9 in patients with various chronic liver diseases and hepatocellular carcinoma. Thromb Haemost 2003; 89(4): 718-25.

[12] Winwood PJ, Schuppan D, Iredale JP, Kawser CA, Docherty AJ, Arthur MJ. Kupffer cell-derived 95-kd type IV collagenase/ gelatinase B: characterization and expression in cultured cells. Hepatology 1995; 22(1): 304-15.

[13] Upadhya AG, Harvey RP, Howard TK, Lowell JA, Shenoy S, Strasberg SM. Evidence of a role for matrix metalloproteinases in cold preservation injury of the liver in humans and in the rat. Hepatology 1997; 26(4): 922-28.

[14] Kuyvenhoven JP, Verspaget HW, Gao Q, et al. Assessment of serum matrix metalloproteinases MMP-2 and MMP-9 after human liver transplantation: increased serum MMP-9 level in acute rejection. Transplantation 2004; 77(11): 1646-52.

[15] Gveric D, Hanemaaijer R, Newcombe J, van Lent NA, Sier CF, Cuzner ML. Plasminogen activators in multiple sclerosis lesions: implications for the inflammatory response and axonal damage. Brain 2001; 124(Pt 10): 1978-88.

[16] Hanemaaijer R, Visser H, Konttinen YT, Koolwijk P, Verheijen $\mathrm{JH}$. A novel and simple immunocapture assay for determination of gelatinase-B (MMP-9) activities in biological fluids: saliva from patients with Sjogren's syndrome contain increased latent and active gelatinase-B levels. Matrix Biol 1998; 17(8-9): 657-65.

[17] Klar E, Angelescu M, Zapletal C, Kraus T, Bredt M, Herfarth C. Definition of maximum cold ischemia time without reduction of graft quality in clinical liver transplantation. Transplant Proc 1998; 30(7): 3683-5.

[18] Strasberg SM, Howard TK, Molmenti EP, Hertl M. Selecting the donor liver: risk factors for poor function after orthotopic liver transplantation. Hepatology 1994; 20(4 Pt 1): 829-38.

[19] Banff scheme for grading liver allograft rejection: an international consensus document. Hepatology 1997; 25(3): 658-63.

[20] Kubben FJ, Sier CF, van Duijn W, et al. Matrix metalloproteinase2 is a consistent prognostic factor in gastric cancer. $\mathrm{Br} \mathrm{J}$ Cancer 2006; 94(7): 1035-40.

[21] Ye S, Dhillon S, Ke X, Collins AR, Day IN. An efficient procedure for genotyping single nucleotide polymorphisms. Nucleic Acids Res 2001; 29(17): E88.

[22] Meijer MJ, Mieremet-Ooms MA, van Hogezand RA, Lamers CB, Hommes DW, Verspaget HW. Role of matrix metalloproteinase, tissue inhibitor of metalloproteinase and tumor necrosis factor- 
alpha single nucleotide gene polymorphisms in inflammatory bowel disease. World J Gastroenterol 2007; 13(21): 2960-6.

[23] Kuyvenhoven JP, Molenaar IQ, Verspaget HW, et al. Plasma MMP-2 and MMP-9 and their inhibitors TIMP-1 and TIMP-2 during human orthotopic liver transplantation. The effect of aprotinin and the relation to ischemia/reperfusion injury. Thromb Haemost 2004; 91(3): 506-13.

[24] Ye S. Polymorphism in matrix metalloproteinase gene promoters: implication in regulation of gene expression and susceptibility of various diseases. Matrix Biol 2000; 19(7): 623-9.

[25] Yu C, Pan K, Xing D, et al. Correlation between a single nucleotide polymorphism in the matrix metalloproteinase-2 promoter and risk of lung cancer. Cancer Res 2002; 62(22): 6430-33.

[26] Zhai Y, Qiu W, Dong XJ, et al. Functional polymorphisms in the promoters of MMP-1, MMP-2, MMP-3, MMP-9, MMP-12 and MMP-13 are not associated with hepatocellular carcinoma risk. Gut 2007; 56(3): 445-7.

[27] Bataller R, North KE, Brenner DA. Genetic polymorphisms and the progression of liver fibrosis: a critical appraisal. Hepatology 2003; 37(3): 493-503.

[28] Benyon RC, Iredale JP, Goddard S, Winwood PJ, Arthur MJ. Expression of tissue inhibitor of metalloproteinases 1 and 2 is increased in fibrotic human liver. Gastroenterology 1996; 110(3): 821-31.

[29] Larrousse M, Laguno M, Segarra M, et al. Noninvasive diagnosis of hepatic fibrosis in HIV/HCV-coinfected patients. J Acquir Immune Defic Syndr 2007; 46(3): 304-11.

[30] Zhang Q, Chen X, Zhou J, et al. CD147, MMP-2, MMP-9 and MVD-CD34 are significant predictors of recurrence after liver transplantation in hepatocellular carcinoma patients. Cancer Biol Ther 2006; 5(7): 808-14.

[31] Lichtinghagen R, Bahr MJ, Wehmeier M, et al. Expression and coordinated regulation of matrix metalloproteinases in chronic hepatitis $\mathrm{C}$ and hepatitis $\mathrm{C}$ virus-induced liver cirrhosis. Clin Sci (Lond) 2003; 105(3): 373-82.

[32] Shin HP, Lee JI, Jung JH, et al. Matrix metalloproteinase (MMP)-3 polymorphism in patients with HBV related chronic liver disease. Dig Dis Sci 2008; 53(3): 823-9.
[33] Minematsu N, Nakamura H, Tateno H, Nakajima T, Yamaguchi K. Genetic polymorphism in matrix metalloproteinase-9 and pulmonary emphysema. Biochem Biophys Res Commun 2001; 289(1): $116-9$.

[34] Jones GT, Phillips VL, Harris EL, Rossaak JI, van Rij AM. Functional matrix metalloproteinase-9 polymorphism (C-1562T) associated with abdominal aortic aneurysm. J Vasc Surg 2003; 38(6): 1363-7.

[35] Hirakawa S, Lange EM, Colicigno CJ, Freedman BI, Rich SS, Bowden DW. Evaluation of genetic variation and association in the matrix metalloproteinase 9 (MMP9) gene in ESRD patients. Am J Kidney Dis 2003; 42(1): 133-42.

[36] Nelissen I, Vandenbroeck K, Fiten P, et al. Polymorphism analysis suggests that the gelatinase B gene is not a susceptibility factor for multiple sclerosis. J Neuroimmunol 2000; 105(1): 58-63.

[37] Krex D, Kotteck K, Konig IR, Ziegler A, Schackert HK, Schackert G. Matrix metalloproteinase- 9 coding sequence single-nucleotide polymorphisms in caucasians with intracranial aneurysms. Neurosurgery 2004; 55(1): 207-12.

[38] Peters DG, Kassam A, St Jean PL, Yonas H, Ferrell RE. Functional polymorphism in the matrix metalloproteinase- 9 promoter as a potential risk factor for intracranial aneurysm. Stroke 1999; 30(12): 2612-6.

[39] Fowell AJ, Benyon RC. Can matrix metalloproteinases be targeted in hepatic ischemia/reperfusion injury? Hepatology 2008; 47(1): 14-6.

[40] Hamada T, Fondevila C, Busuttil RW, Coito AJ. Metalloproteinase-9 deficiency protects against hepatic ischemia/reperfusion injury. Hepatology 2008; 47(1): 186-98.

[41] Okamoto K, Mimura K, Murawaki Y, Yuasa I. Association of functional gene polymorphisms of matrix metalloproteinase (MMP)-1, MMP-3 and MMP-9 with the progression of chronic liver disease. J Gastroenterol Hepatol 2005; 20(7): 1102-8.

[42] Hove WR, van Hoek B, Bajema IM, Ringers J, van Krieken JH, Lagaaij EL. Extensive chimerism in liver transplants: vascular endothelium, bile duct epithelium, and hepatocytes. Liver Transplant 2003; 9(6): 552-6.

[43] Han YP. Matrix metalloproteinases, the pros and cons, in liver fibrosis. J Gastroenterol Hepatol 2006; 21(Suppl 3): S88-S91.

(c) ten Hove et al.; Licensee Bentham Open.

This is an open access article licensed under the terms of the Creative Commons Attribution Non-Commercial License (http: //creativecommons.org/licenses/ by-nc/3.0/) which permits unrestricted, non-commercial use, distribution and reproduction in any medium, provided the work is properly cited. 